\title{
Endophytic Bacteria as Biocontrol Agents of Tomato Bacterial Wilt Disease
}

\author{
Arika Purnawati ${ }^{1,2 *}$, Ika Rochdjatun Sastrahidayat ${ }^{3}$, Abdul Latief Abadi ${ }^{3}$, Tutung Hadiastono ${ }^{3}$ \\ ${ }^{1}$ Faculty of Agriculture, UPN “Veteran” East Java, Surabaya, Indonesia \\ ${ }^{2}$ Postgraduate Program, Faculty of Agriculture, Brawijaya University, Malang, Indonesia \\ ${ }^{3}$ Faculty of Agriculture, Brawijaya University, Malang, Indonesia
}

\begin{abstract}
Ralstonia solanacearum is a tomato pathogen causing wilt disease which can lose crop production up to $100 \%$. This problem also has economical impact to Indonesia, though controlling this pathogen has been done before. Biological control using endophytic bacteria is one of alternative control methods to support agriculture sustainability. The objective of these experiments are isolating endophytic bacteria taken from healthy tomato stems and root as well as investigating patogens as biocontrol agents of tomato bacterial wilt disease. Among 10 isolates found, only Ps1 and Ps 8 can inhibit R. solanacearum based on antagonistic test in vitro using seed coat method and 4-7 mm inhibition zone forming. In vivo test was applied in green house in 30 days old of tomatoes using endophytic bacteria by the root soak technique. The result shows Ps1 and Ps 8 within 15-16 days incubation period have suppressed $8.07 \%-9.19 \%$ pathogen attack.
\end{abstract}

Keywords: biocontrol, endophytic bacteria, R. solanacearum

\section{INTRODUCTION}

Ralstonia solanacearum, the causal agent of bacterial wilt disease, is an important pathogen because it damages tomato in Indonesia and can lose yields up to $100 \%$ [1]. Farmers had controlled the disease by using several methods, including cultivation techniques, physical treatment, use of resistant varieties, bactericide and antibiotics application; yet, all of the techniques did not reduce the level of disease [2]. On the basis of the previous experiences, the biocontrol method using biocontrol agents was investigated. Several endophytic bacteria were explored for biocontrol agents for the disease.

Endophytic bacteria is a group of microbes that live in plant tissue, without plant disease and related plants in mutualism simbiosis. Endophytic bacteria live in healthy tissues such as seeds, roots, stems and leaves. Plants benefit from the presence of endophytic bacteria because it produces compounds or secondary me

\footnotetext{
*Corresponding author:

Arika Purnawati

Faculty of Agriculture, UPN “Veteran” East Java, Surabaya, Indonesia

E-mail: ikahptupn@gmail.com
}

tabolites and antibiotics that stimulate growth hormone to affect plant growth and increases plant resistance to pathogens [3, 4]. Endophytic bacteria can be isolated from the roots, stems, flowers and cotyledons, which are the spaces between cells in a tissue or vessel [5].

The objective of these experiments are to select endophytic bacteria isolated from tomato stems and root as well as to investigate them as biocontrol agents of tomato bacterial wilt disease.

\section{MATERIALS AND METHODS}

\section{Isolation of R. Solanacearum}

The isolation was carried out by using the solution technique according to [6] as follows: stems of tomato plants were cut along the 0.5 $\mathrm{cm}$, then disinfected by soaking them in $70 \%$ alcohol followed by washing them by using sterile water three times. Then they were put into a test tube plus $10 \mathrm{ml}$ of sterile water and left for some minutes until the mass of bacteria out and dissolved in sterile water. The mass of bacteria in sterile water was shaken by using a vortex mixer type Maxi Mix II Thermolyne M37610-33 to form a suspension. The suspension was streaked by using a needle ose in TZC medium and incu- 
bated in incubator at room temperature $\left(28^{\circ} \mathrm{C}\right)$ for 48 hours.

\section{Isolation of Endophytic Bacteria Isolation from stem}

The stem with $50 \mathrm{~cm}$ long from the base was washed with water to clean the surface, then cutting it into parts with each part was $1 \mathrm{~cm}$ long. The specimen was sterilized by using $\mathrm{NaOCl}$ $1.25 \%$ for 1 minute, dyed in absolute alcohol for $5 \mathrm{sec}$ (done 3 times), dipped in sterile water for 5 $\sec (3$ times), then dying the specimen on a sterile filter paper in laminar air flow (LAF) for 5 minutes [7]. The spesimen was splitted into two parts and inoculated on PDA medium (Difco USA): $39 \mathrm{~g} / 1, \mathrm{pH} 7.0$ in a sterile Petri dish with the inner surface touching medium or tummy position. Then, it was incubated in incubator at room temperature $\left(28^{\circ} \mathrm{C}\right)$ for 48 hours. After endophytic microbes grew, they were inoculated on sterile PDA medium for fungi and the NA medium NA (Difco USA): $8 \mathrm{~g} / 1, \mathrm{pH} 7.0$ for bacteria to obtain pure cultures.

\section{Isolation from root}

All parts of the roots were washed with water to clean the surface, then cutting them into parts with $1 \mathrm{~cm}$ long. The specimen was sterilized by using $\mathrm{NaOCl} 1.25 \%$ for 1 minute, dyed in absolute alcohol for $5 \sec$ (3 times), dipped in sterile water for $5 \mathrm{sec}$ ( 3 times). Then, the specimen was dried on sterile filter paper in laminar air flow (LAF) for 5 minutes [7]. The spesimen is inoculated on PDA medium (Difco USA): 39 $\mathrm{g} / 1, \mathrm{pH} 7.0$ with an upright position on the medium so the pieces touched the bottom of the medium. Then, they were incubated in incubator at room temperature $\left(28^{\circ} \mathrm{C}\right)$ for 48 hours. After endophytic microbes grew, they were inoculated on sterile PDA medium for fungi and the NA medium for bacteria to obtain pure cultures.

\section{Antagonistic Test in vitro}

Antagonism test was done in laboratorium by using the seed coat method. The procedure was as follows. The tomato seeds that would be used were sterilized by using klorok $1 \%$ for $30 \mathrm{sec}$. Then, they were rinsed 3 times in sterile water and dried on sterile tissue paper. The seeds were soaked into suspension of endophytic bacteria with $108 \mathrm{cfu} / \mathrm{ml}$ concentration. This lasted in 10 , $30,60,90,120$ minutes before they were inoculated on NA medium and were incubated in incubator for 24 hours at room temperature $\left(28^{\circ} \mathrm{C}\right)$. After 24 hours, a cup of Petridish was spilled in $1 \mathrm{ml}$ of chloroform within about 2 hours, then closing it and the Petridish was put back in its original position. The observed variable was the inhibition zone around the seed. Antagonism test used completely randomized design with 2 factors, that is, endophytic bacteria isolates (Ps1, Ps2) and seed soaking time (30, 60 min) with 3 replications. The data were analyzed statistically using LSD 5\%.

\section{Effectiveness test in vivo}

The effectiveness test in vivo was carried out in green house by using the root soaking method, the procedure of which was as follows. The inoculation of $R$. solanacearum was carried out in 2 days before planting tomato plants using the flush technique of suspensing $R$. solanacearum to soil. Endophytic bacteria was inoculated by using the root soaking technique in $100 \mathrm{ml}$ suspension of endophytic bacteria for 60,90 mins. Then, the tomato plants were planted in soil that had been inoculated by $R$. solanacearum. The observed variables were the incubation period and the disease incidence during 60 days. Effectiveness test used completely randomized design with 2 factors, that is, endophytic bacteria isolates (Ps1, Ps2) and root soaking time (60, 90 $\mathrm{min})$ with 3 replications. The data were analyzed statistically using LSD 5\%.

\section{RESULTS AND DISCUSSION}

The result of these experiments are 10 isolates of endophytic bacteria which were isolated from the stem and root of tomato plants. Two isolates, Ps1 and Ps8, are found to inhibit R. solanacearum based on antagonistic test in vitro using the seed coat method and its ability to suppress wilt disease in vivo test in green house.

\section{Antagonistic Test in vitro}

The result of antagonistic test of two isolates endophytic bacteria shows that there is no different at LSD 5\% analysis, but there is an increase in size of inhibition zone at 48 hours of observation (Table 1 and Figure 1) and inhibition mechanism is antibiosis as bacteriostatic. The reason of the result because the time for the production of antibiotic by endophytic bacteria is enough, and the molecule can adhere the surface of tomato seed coat that is semipermeable. Another probable reason is that it produces siderophore that is a compound containing hidroksamat and catechol molecules, being two 
molecules which adhere to the surface of tomato seed coat that is semipermeable. Both of them probably have smaller molecular size than fat and protein, so they are able to diffuse and adhere to the surface of the tomato seed coat. Seed coat is composed of $\mathrm{Ca}, \mathrm{Na} \mathrm{Fe}, \mathrm{Mg}$, proteins, phenols, and is semipermeable [8].
Diversified chemical composition of the semipermeable layer seed coat of $\mathrm{R}$. nutans, $A$. inebrians, Triticale, and $H$. vulgare var. nudum contains lipids in the semipermeable layer of seed coat [9]. F. sinensis seed coat has pectine and seed coat. The inhibition zone in antagonistic test against $R$. solanacearum is an antibiosis mechanism as bac-

Table 1. Antagonistic Test Endophytic Bacteria to R. solanacearum using Seed Coat Method In Vitro

\begin{tabular}{|cccccc|}
\hline Treatment & $\begin{array}{c}\text { Time of Seed } \\
\text { Soaking } \\
\text { (min) }\end{array}$ & 24 & \multicolumn{4}{c|}{$\begin{array}{c}\text { Size of inhibition Zone } \\
(\mathrm{mm}) \text { After Treatment (hours) }\end{array}$} \\
\cline { 3 - 6 } & & 0 & 48 & 72 & 06 \\
\hline Control & 30 & 4 & 4 & 6 & 0 \\
Ps $_{1}$ & 60 & 6 & 6 & 7 & 7 \\
& 30 & 4 & 4 & 5 & 5 \\
Pss $_{8}$ & 60 & 6 & 6 & 7 & 7 \\
\hline
\end{tabular}
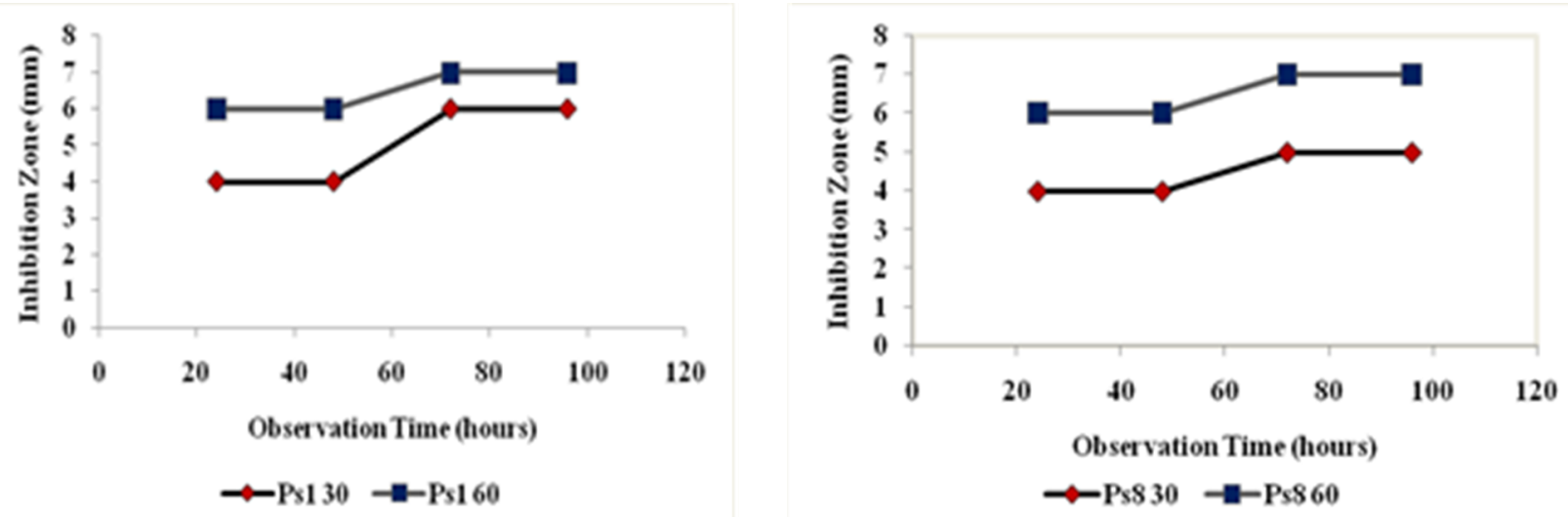

Figure1. Curva of Inhibition Zone Endophytic Bacteria to R. solanacearum

teriostatic and the evidence was proven by taking the zone and inoculating it into peptone $0.5 \%$ solution. The result is that the solution is turbid.

\section{Effectiveness test in vivo}

The result of effectiveness test of two isolates endophytic bacteria are incubation period 15-16 days and they significantly suppress disease incidence until 8.07-9.19\% (Table 2), although there is no different at LSD 5\% analysis for treatment. The reason behind such a result is because the disease development is influenced by environment including the temperature $\left(34^{\circ} \mathrm{C}\right)$, the humidity (80\%), which serve as an ideal condition for producing antibiotic and siderophore. These two substances can form a systemic resistance induction, so that disease incidence decreases. It has been known that temperature supporting

Tabel 2. Disease Incidence of Wilt R. solanacearum in Vivo

\begin{tabular}{|c|c|c|c|c|c|c|c|}
\hline \multirow[t]{2}{*}{ Treatments } & \multicolumn{7}{|c|}{ Disease Incidence $(\%)$ at ... dat } \\
\hline & 14 & 21 & 28 & 35 & 42 & 49 & 56 \\
\hline Control & $3,52 a^{*}$ & $13,50 \mathrm{a}$ & 13,50 a & $18,13 \mathrm{a}$ & 18,13 a & 18,13 a & $18,13 \mathrm{a}$ \\
\hline $\mathrm{Ps}_{1}$ & $0,17 \mathrm{~b}$ & $3,75 \mathrm{~b}$ & $3,75 \mathrm{~b}$ & $7,50 \mathrm{~b}$ & $7,50 \mathrm{~b}$ & $7,50 \mathrm{~b}$ & $9,50 \mathrm{~b}$ \\
\hline $\mathrm{Ps}_{8}$ & $0,17 \mathrm{~b}$ & $5,25 \mathrm{~b}$ & $5,25 \mathrm{~b}$ & $8,75 \mathrm{~b}$ & $8,75 \mathrm{~b}$ & $8,75 \mathrm{~b}$ & $10,25 \mathrm{~b}$ \\
\hline BNT $5 \%$ & 0,18 & 1,50 & 1,50 & 2,13 & 2,13 & 2,13 & 2,96 \\
\hline
\end{tabular}

Note: *figures in the same column and follow by the same letter are not significantly different at LSD $5 \%$, dat : days after treatments 
the development of disease is $25-35^{\circ} \mathrm{C}$ with humidity level of $86 \%$ [11], while the incubation period of $R$. solanacearum on potato varieties varies from 6.5-21.3 days [12]. Another reason is that because they produce antibiotic and siderophore, the two of which are induction resistance gens of tomato plants against R. solanacearum. The effectiveness of biological control using biocontrol agents can be enhanced through the application of techniques like soaking the roots. Previous study stated that P. PfG32 fluorescens that are isolated from rhizosphere of onion actively suppress the incidence of bacterial wilt in tomatoes because it produces siderophores and antibiotics [13].

The effectiveness of biological control using biocontrol agents can be enhanced through the application of different techniques like soaking the roots or seeds before transplanting and it gives the effect of more rapid induction of resistance [14].

\section{CONCLUSION}

From the present research, two isolates of endophytic bacteria $\left(\mathrm{Ps}_{1}, \mathrm{Ps}_{8}\right)$ can inhibit $\mathrm{R}$. solanacearum in vitro $4-7 \mathrm{~mm}$ and in vivo significantly suppresses wilt disease up to 8.07$9.19 \%$ with the incubation period of 15-16 days.

\section{ACKNOWLEDGEMENTS}

Thanks to Scholarship for Postgraduate (BPPS) provided by the Directorate General of Higher Education (DIKTI) and University National Development "Veteran" East Java that support this research.

\section{REFERENCES}

1. Nurrjanani (2011) Kajian pengendalian Penyakit layu bakteri (Ralstonia solanacearum) menggunakan agen hayati pada tanaman tomat. Suara Perlindungan Tanaman. 1 (4): 1-8.

2. Commenwealth Agriculture and Bioscience (CABI) (2013) Invasive Species Compendium Ralstonia solanacearum.

3. Hundley NJ (2005) Structure Elucidation of Bioactive Compounds Isolated from Endophytes of Alstonia scholaris and Acmena graveolens. MS thesis. Univ. of Brigham Young.

4. Bandara WMMS, Seneviratne G, Kulasooriya SA (2006) Interactions among endophytic bacteria and fungi : effects and potentials. J. Biosci. 31(5): 645-650.
5. Athman SY (2006) Review of the role of endophytes in biological control of plant parasitic nematodes with special reference to the banana nematode Radopholus similis. MS thesis. Univ. of Pretoria. South Africa.

6. Sastrahidayat IR, Djauhari S (2012) Teknik Penelitian Fitopatologi. UB Press. Malang.

7. Widayanto EB (2008) Utilization of endophytic fungus Fusarium as biological control agents Fusarium oxysporum cause fusarium wilt on banana. PhD. dissertation. UB.

8. Oseni OA, Olarinoye CO, Amoo IA (2011) Studies on chemical compositions and functional properties of thorn apple (Datura stramonium L). African Journa of Food Sci. 5(2): 40-44.

9. Zhou J, Wang Y, Jahufer Z (2013) Location and chemical composition of semipermiable layer forage seeds. Bangladesh J. Bot. 42(1): 23-29.

10. Djatmiko HA, Arwiyanto $T$, Hadisutrisno $B$, Sunarminto BH (2007) Potention of three genera of bacteria from three of crop rhizospere as bological control agent of the lincat disease. J. Of Agric. Sci. 9(1): 40-47.

11. Fajinmi AA, Fajinmi OB (2010) An overview of bacterial disease of tomato in Nigeria. J. Agric. 5(4): 242-247.

12. Sastra DR (2009) Masa inkubasi bakteri patogenik Ralstonia solanacearum RAS 3 pada beberapa klon Kentang. J. Agronomi. 8(1): 63-67.

13. Mulya K, Watanabe M, Goto M, Takikawa Y, Tsuyumu S (2006) Suppression of bacterial wilt disease in tomato by root dipping with Pseudomonas fluorescens PfG32 : the role of antibiotic substances and siderophore production. Ann. Phytopathol. Soc. Jpn. 62: 134140.

14. Hallmann JS (2001) Bacterial endophytes in cotton : mechanisms of entering the plant. Can. J. Microbiol. 43 : 577-582. 